\title{
The levels of fluorine in the sediments of the aquifer and their significance for fluorosis in coastal region of Laizhou Bay, China
}

\author{
Qiao Chen • Qingshui Lu - Zhaojun Song • \\ Peng Chen $\cdot$ Yukun Cui $\cdot$ Rui Zhang $\cdot$ \\ Xiaohui Li $\cdot$ Jingyuan Liu
}

Received: 5 December 2012/Accepted: 3 October 2013/Published online: 15 October 2013

(c) Springer-Verlag Berlin Heidelberg 2013

\begin{abstract}
The levels of fluorine in sediment cores obtained from Changyi County (PZ core) and Laizhou County (TS core) are used to discuss the fluorine sources in groundwater and its enrichment dynamics. The sediments in the aquifer are mainly constituted of granite gravels. The levels of fluorine in the PZ and TS cores range from 130 to $468 \mathrm{mg} / \mathrm{kg}, 139-528 \mathrm{mg} / \mathrm{kg}$, with average values of 324 , $348 \mathrm{mg} / \mathrm{kg}$, respectively, which show relatively lower levels than the national average of fluorine in the soil or sediment. Thus, the fluorosis in this area should not be attributed to the levels of fluorine in sediments. The average fluorine concentrations in the aquifer from top to bottom are 154, 139, 200, $222 \mathrm{mg} / \mathrm{kg}$ for the TS core, and 154, $130,266,272 \mathrm{mg} / \mathrm{kg}$ for the PZ core, respectively, which are the lowest of the cores and extremely lower levels than the fresh granites. Such a fact indicates that a vast amount of fluorine has been leached into the groundwater. Moreover, the fluorine leachability is estimated to be approximately $70 \%$, although the previous documents showed fluorine contents of the granite surrounding Laizhou Bay were almost equal to or even lower than the average levels of fluorine in fresh granites. Meanwhile, a simulation experiment also reveals that fluorine release from rocks increases with the addition of seawater and brine water.
\end{abstract}

Q. Chen $(\bowtie) \cdot$ Z. Song $\cdot$ P. Chen · Y. Cui · R. Zhang · X. Li · J. Liu

Shandong Provincial Key Laboratory of Depositional

Mineralization and Sedimentary Minerals, College of Geological Sciences and Engineering, Shandong University of Science and Technology, Qingdao 266590, China

e-mail: qchen5581@163.com

Q. Lu

Yantai Institute of Coastal Zone Research, Chinese Academy of Sciences, Yantai City 264003, China
Therefore, the seawater intrusion may potentially enhance the fluorine leachability, and should be an important dynamic of fluorine enrichment.

Keywords Fluorine contents · Sediment · Fluorosis . Laizhou Bay $\cdot$ Seawater intrusion

\section{Introduction}

Fluorine is a widespread, chemical element in the geographical environment and of great importance for human health, particularly for the preservation of teeth and bones. However, excessive intake causes dental or skeletal disease, known as fluorosis (WHO 1984; Harrison Paul 2005). The development and occurrence of fluorosis originate from high fluorine content in the soil, air or water. Water is perhaps the major contributor (Chen et al. 2011, 2012). Fluoride concentrations in water and the health problems it causes have been the subject of numerous studies in recent years (Gaciri and Davies 1993; Apambire et al. 1997; Fantong et al. 2010).

Universal, water-drinking endemic fluorosis occurs in Laizhou Bay, an area in the northern, coastal region of Shandong Province, China. It is estimated that more than 640,000 people are suffering from dental or skeletal fluorosis because of long-term consumption of fluoride-contaminated water (Han 1997). Fluorine contamination of the water can reach more than $12 \mathrm{mg} / \mathrm{L}$ (Yun et al. 2005). Moreover, fluorosis has been on the rise and new areas have been appearing in recent years (Yun et al. 2005; Gao et al. 2007a).

The amount of naturally occurring fluorine in groundwater is governed principally by hydrogeology, climate, the composition of the host rock, depletion of groundwater 
table, anthropogenic activities such as the use of pesticides, phosphatic fertilizer, dumping industrial sewage and sludge and so on (Ramanaiah et al. 2006). However, the majority of fluoride is derived from rock minerals on the earth's surface, whereas other sources such as air, seawater, and human activities constitute a relatively small proportion (Fuge 1988; Lahermo et al. 1991). Therefore, the main source of fluorine in groundwater is considered to be the fluorine-bearing minerals such as fluorspar, cryolite, hydroxy apatite and fluorapatite in rocks (Farooqi et al. 2007) under prolonged exposure to water (Carrillo-Rivera et al. 2002).

In the areas affected by fluorosis in Laizhou Bay, many investigations have been made related to the levels of fluorine in water, epidemiology and the correlation of fluorine with some inorganic constituents (Yun et al. 2005; $\mathrm{Li}$ 2007). The scope of distribution and the health-related impacts of high fluorine groundwater in this area are well known. However, a bibliographic survey showed that no researches have detailed the fluoride source, genesis and the processes that induced fluorine enrichment so far in this area. Therefore, an investigation of the level of fluorine in the sediment of aquifer is necessary for the scientific management, sustainable use of groundwater and the prevention of fluorosis.

In this experiment, two drills were carried out to obtain two sediment cores in Laizhou County and Changyi County, respectively. These areas have serious problems with fluorosis. The levels of fluorine in the sediment of the aquifers were studied to determine the interactions between the water, rock or sediments, which is ultimately expected to observe the peculiar geochemical features in the aquifer. The present study was conducted to: (1) reveal the characteristics of sediments in the aquifer and the geological setting of fluorine enrichment in these areas; (2) estimate the level of fluorine in the sediment/soil, and discuss its relationship with high fluorine level in the groundwater; and (3) evaluate the fluorine leachability in the aquifer and discuss the possible dynamics.

\section{Sampling and analysis}

Site description

Laizhou Bay is located in the northern part of Shandong Province, China, which is adjacent to Bohai Sea and Yellow Sea (Fig. 1). Its basement is a metamorphic sequence formed during the Archaean-Proterozoic Period. The sedimentary cover consists mainly of the Early Cretaceous Qingshan Formation, the Eocene Huangxian Formation, basalt and the Quaternary. The former is scarcely exposed and sporadically distributed around the border of this area.
From Hutouya, through Changyi and Shouguang Counties, to the west of Xiaoqing River, the Quaternary comprises the Upper Pleistocene and Holocene Periods. The Upper Pleistocene layer, which consists of alluvial or diluvial, mild clay, sandy clay, fine to coarse sands and gravels, usually $10-100 \mathrm{~m}$ in thickness, is the main aquifer in the study area. Three brine/salt aquifers occur, respectively, in the Holocene, Upper Pleistocene and Lower Pleistocene (Xue et al. 1998).

Two cores were extracted in 2009 in the northern part of Tushan Town, Laizhou City and Puzhuang Town, Changyi City. The two towns have severely high fluorine contamination in the groundwater (Han 1997; Chen et al. 2011). There were an estimated 93,388 cases of dental or skeletal fluorosis in Changyi City and 15,600 cases of dental or skeletal fluorosis in Laizhou City in 2001. In addition, the region suffers from seawater intrusion as a result of its close proximity to the Bohai Sea, including modern seawater and the brine/salt (paleo-seawater) intrusion (Meng et al. 2002).

Sampling and analysis methods

The sedimentary cores were obtained with a piston corer. The locations of the cores are shown in Fig. 1. The core from Tushan Town (TS) was extracted from the northern part of Laizhou City, with the geographical coordinate of $\mathrm{N} 37^{\circ} 06.5460^{\prime}, \mathrm{E} 119^{\circ} 40.1753^{\prime}$. The core from Puzhuang

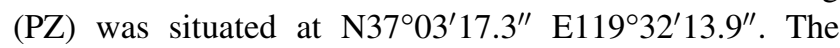
length of TS sediment core is $40 \mathrm{~m}$, and the PZ core is $80 \mathrm{~m}$. Both of the core samples represent a cross-section of the four, main aquifers.

The cores were cut into sections according to the description of lithology. Then, the sections were sealed in plastic tapes and expeditiously sent to a laboratory. Half of the sediments were frozen until further analysis could be performed. The remainder was dried at room temperature, ground using an agate mortar and pestle; and a fraction was passed through a $2 \mathrm{~mm}$ sieve, and then it was collected for analysis. The method to determine the fluorine content was designed by McQuaker and Gurney (1977) utilizing a fluoride selective electrode (DZ/T0167-2006). The accuracy of analysis was checked by comparing the samples with the standard, controlled samples, and the errors for all analyzed samples proved to be less than $5 \%$.

Simulation experiment methodology of fluorine leaching ability

To directly reveal the dynamics of groundwater fluorine enrichment in coastal areas, a fluorine leaching experiment of rocks was conducted in laboratory. The starting 


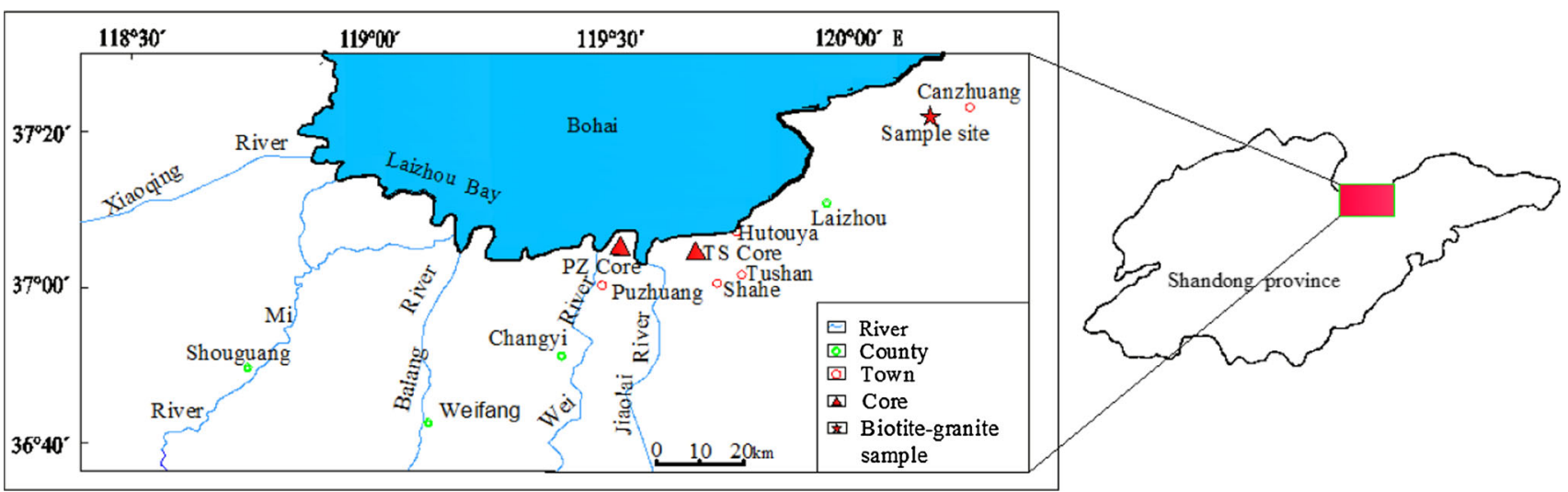

Fig. 1 Geographical map of Laizhou Bay and the sampling sites

materials were fresh water, seawater, brine water, and the biotite granites.

Two types of seawater intrusion are involved along Laizhou Bay: modern seawater intrusion and brine/saline water intrusion derived from paleo-seawater in shallow Quaternary sediments (Meng et al. 2002; Chen et al. 2012). Hence, the fresh water, fresh water and seawater of 1:1, and seawater were used to determine the difference of fluorine leachability with the addition of seawater. The fresh water, fresh water and brine water of $1: 1$, and brine water were used to reveal the difference of fluorine leachability with the addition of brine water. Totally, five solutions were prepared.

Fluorine enriches in late-stage pegmatite granites because it is an incompatible element, and fluorine is associated with biotite due to its similar radius to $\mathrm{OH}^{-}$. Therefore, the biotite granites have high fluorine levels and are used as experiment samples in this study. The rock samples were collected from Moshan magmatic body in Canzhuang Town, Yantai City, Shandong Province, a representative outcrop of biotite granite (Fig. 1). The magmatic body lies in the northeast of the sediment cores and belongs to Linglong-type granite. The rocks are approximately composed of $40 \% \mathrm{~K}$-feldspar, $30 \%$ plagioclase, 25-26\% quartz and 3-5\% biotite; and some accessory minerals as magnetite, garnet, and allanite were detected in small concentrations (Luo and Miao 2002).

The rock samples were crushed into particles less than 100 mesh. Five 1,000 ml beakers were pre-cleaned and $50 \mathrm{~g}$ of the sample was added into each beaker. Then, the beakers were immersed, respectively, with $1,000 \mathrm{ml}$ of the prepared five solutions and placed on bench; $120 \mathrm{ml}$ supernatant were withdrawn from each beaker with a syringe on various occasions (8, 16, 24, 48, 96 and $192 \mathrm{~h}$ ). Every beaker was shaken by magnetic stirrer for $1 \mathrm{~min}$ to facilitate mixing after each sampling (Fig. 2). The fluorine levels of the solutions were determined using fluorine selective electrode.

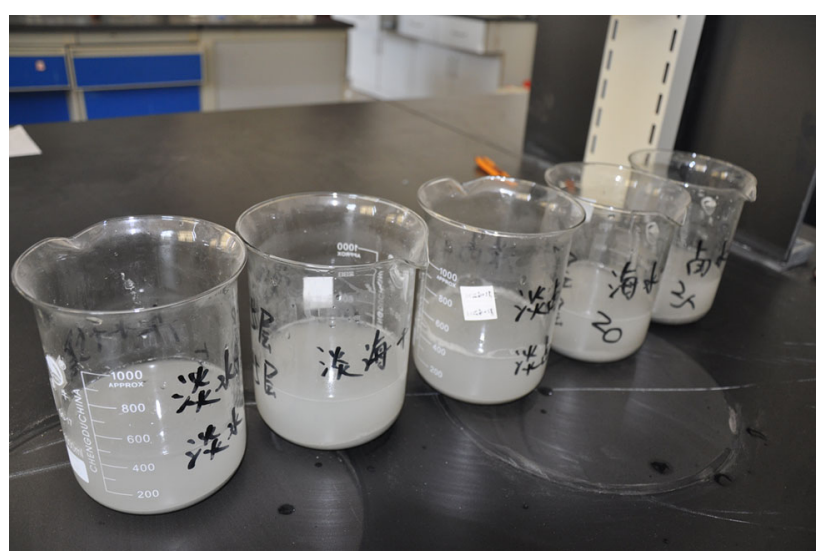

Fig. 2 The simulation experiment in laboratory

\section{Results and discussions}

Sediment characteristics of the aquifer

The sedimentary structure, colors and classified sedimentary facies were described on each section of the two cores as shown in Fig. 3. The two cores are mainly composed of clay, silt clay, and small amounts of coarse sand with granule gravels. Four aquifers were found at 25.9-34.7, $46.9-51,60.5-62,71.9-79.3 \mathrm{~m}$ in the PZ core and $13.5-15.7,17.8-18.9,25.1-27.0,30.2-36.5 \mathrm{~m}$ in the TS core. In addition, two calcareous nodule layers were observed at a depth of 41-41.5 and 56.95-57.1 $\mathrm{m}$ in the PZ core.

The sediments of the four aquifers were photographed in Figs. 4 and 5. Both cores revealed that the aquifers are mainly composed of granite gravels. Fluorine is classified as an incompatible, lithophile element (Faure 1991), which means that it preferentially partitions into melts as magmatic crystallization proceeds (Xiong and Zhu 1998). As a result, hydrothermal vein deposits, late-stage pegmatite granites and rocks that crystallize from highly evolved 
Fig. 3 The lithology and fluorine contents of the two sediment cores
Core: PZ in Changyi County

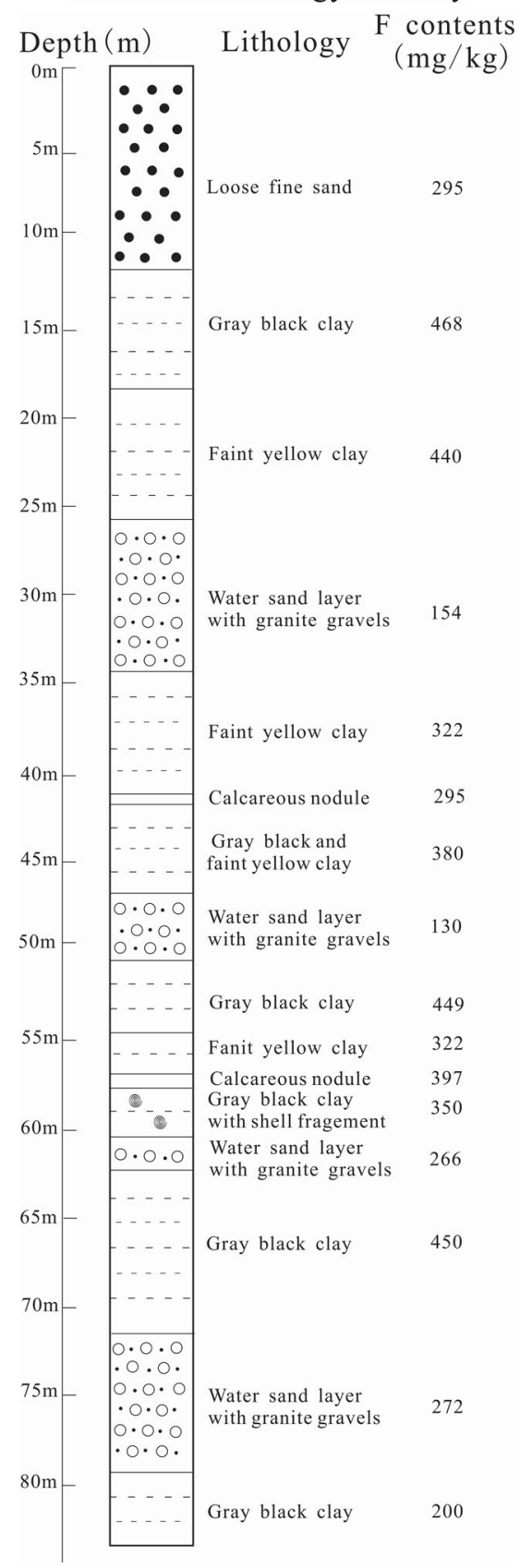

Core: TS in Laizhou County

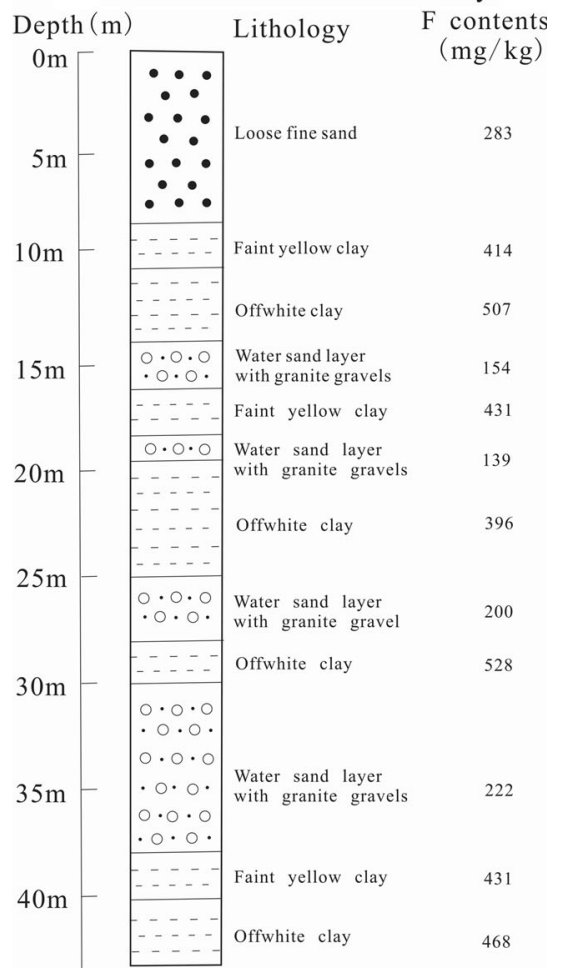

magmas often contain fluorapatite, fluorite and fluorideenriched micas and/or amphiboles (Nagadu et al. 2003; Taylor and Fallick 1997; Scaillet and Macdonald 2004).

Fluorite is considered as the dominant source of fluoride in groundwater, especially in granitic terrains (Kim and Jeong 2005). However, its solubility and dissolution rate is slow (Kim and Jeong 2005). Therefore, some researchers suggest that minerals influencing the hydrogeochemistry of fluoride include apatite, cryolite, villiaumite and silicates such as the double-chain silicates of amphiboles, the phyllosilicates of micas, and the phyllosilicates of clays where $\mathrm{F}^{-}$and $\mathrm{OH}^{-}$substitutes for each other within their octahedral sheet (e.g., Chae et al. 2006; Subba Rao and John Devadas 2003). Therefore, the minerals of the granite gravels in this area seem to provide fluorine ions. In fact, a number of researches argued that fluorine leaching into the groundwater is associated with granite and gneiss. Chae et al. (2007) confirmed that the high levels of fluoride in the groundwater in South Korea have been identified in the sedimentary aquifers that are made up of fluoride-bearing minerals derived from parent rocks of granites. Fantong et al. (2010) reported that the occurrence of toxic 


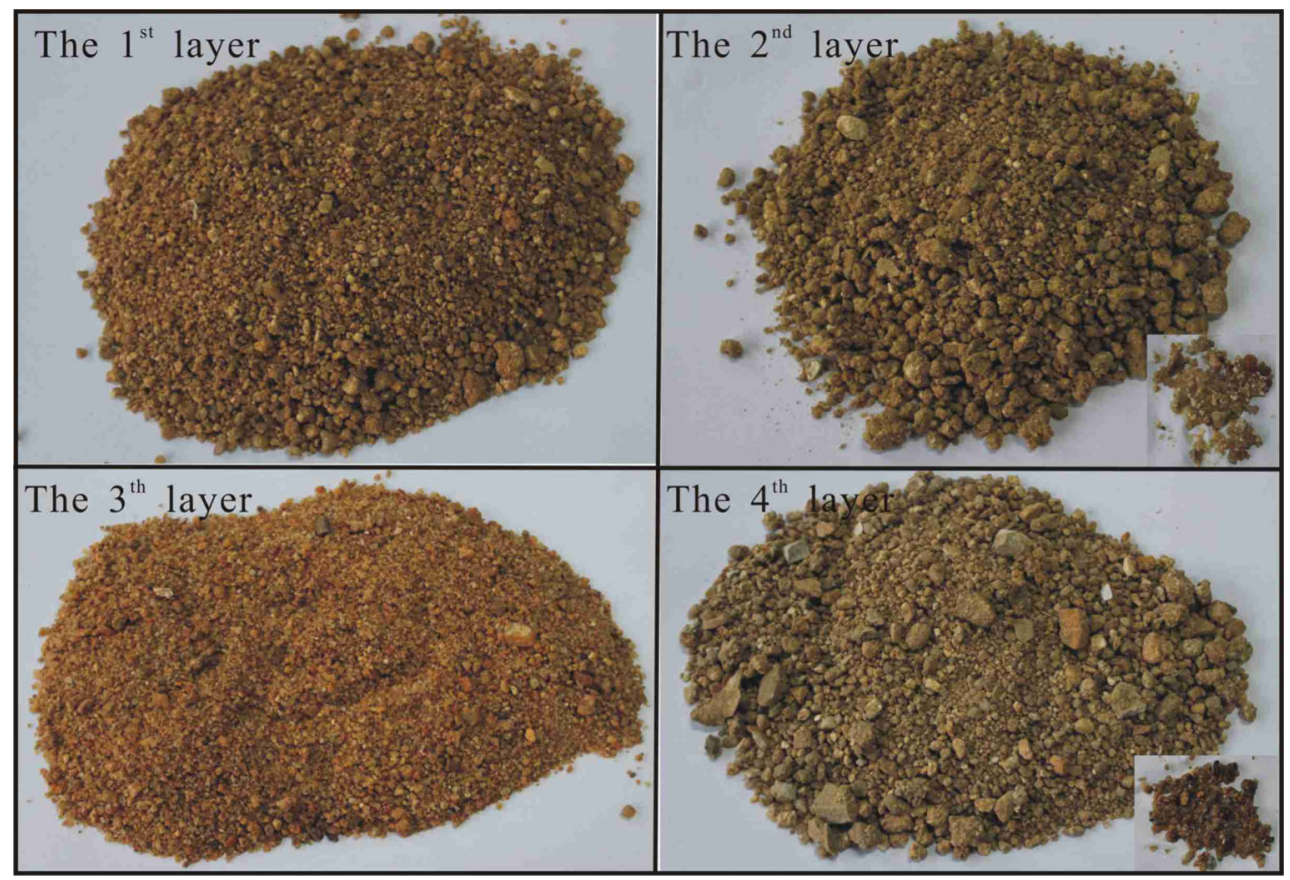

Fig. 4 The sediments in the aquifers of the TS cores (the pictures on the lower right present the wet sediment)

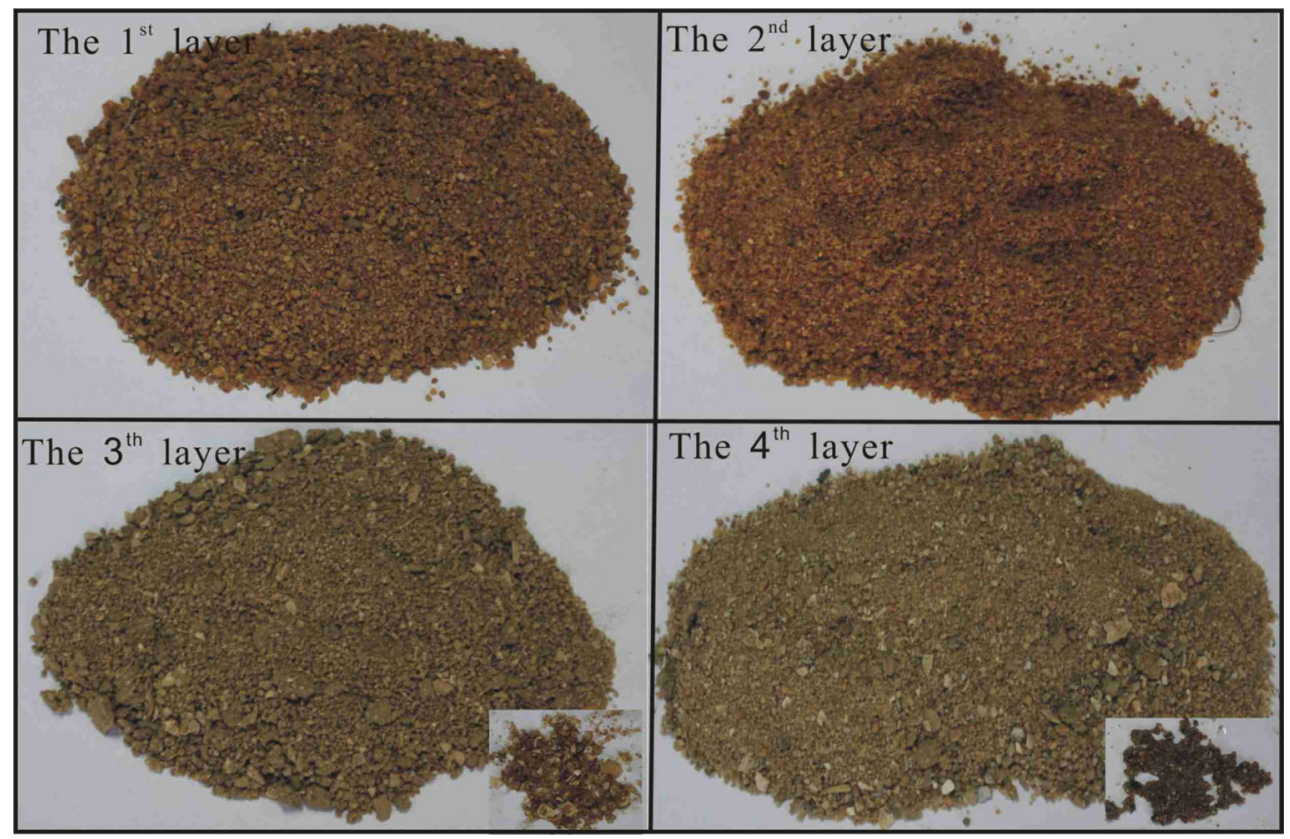

Fig. 5 The sediments in the aquifers of the PZ cores (the pictures on the lower right present the wet sediment)

concentrations of fluoride in groundwater in Mayo Tsanaga River Basin, Cameroon is linked to dissolution of fluoriderich minerals in the granites. Valenzuela-vasquez et al. (2006) stated that the fluoride in the groundwater supply to Hermosillo City, Sonora, Mexico originates from granites from the Sierra Bachoco basement. In other places such as Kitakami Mountains, Northeast Japan (Kanisiwa 1979), Sor Rondane Mountains, East Antarctica (Li et al. 2003),
Nalgonda District, India (Reddy et al. 2010), granites are proved to provide abundant concentrations of fluoride in groundwater. The authors' observations are in agreement with these results.

Granites occur widely, surrounding the coastal region of Laizhou Bay, especially in the northwest part (Fig. 6). Luo and Miao (2002) classified the granites into Aishan-type, Guojialing-type, Luanjiahe-type and Linglong-type and 


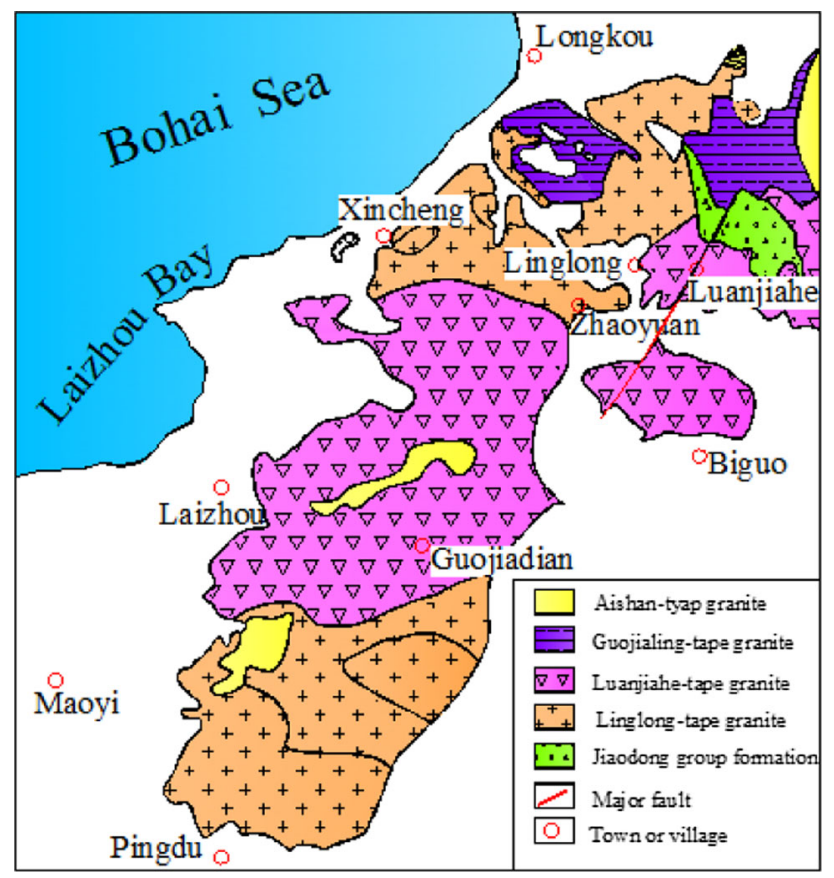

Fig. 6 Granites surrounding Laizhou Bay (after Luo and Miao 2002)

concluded that the granites were formed during late Yanshanian Phase of Mesozoic Period.

There are few reports detailing the sources and enrichment dynamics of groundwater with high levels of fluorine in Laizhou Bay. Li (2007) reported that the surrounding Cretaceous clastic, lava rocks of the Qingshan Group and sedimentary clastic rocks of the Wangshi Group are the sources of fluorine, due to the relative high contents and leaching coefficients of fluorine. But the data show its levels of fluorine vary from 440 to $600 \mathrm{mg} / \mathrm{kg}$, which are equal to or even lower than the national average of $625 \mathrm{mg} /$ $\mathrm{kg}$ in rock (Xie et al. 1999). The authors' investigation suggests that the source of fluorine should be focused around the granites of the Yanshanian Phase in the coastal area of Laizhou Bay.

Fluorine contents of sedimentary cores

The levels of fluorine in the sediment of the four aquifers are listed in Fig. 3. The fluorine level of the TS core ranges between 139 and $528 \mathrm{mg} / \mathrm{kg}$, with an average of $348 \mathrm{mg} /$ $\mathrm{kg}$. The PZ core has fluorine levels as high as $130-468 \mathrm{mg} /$ $\mathrm{kg}$ and a mean of $324 \mathrm{mg} / \mathrm{kg}$. The national average of fluorine in the soil or sediment is $453 \mathrm{mg} / \mathrm{kg}$. Wang and Wei (1995) summarized soil samples developed from different rocks in China and proposed that the average value is much higher. Therefore, the cores in this area show a relatively lower level of fluorine, and fluorine enrichment in the groundwater should not be attributed to the sediment itself in this area. The levels of fluorine in the TS core are in this order: off-white clay $>$ faint yellow clay $>$ loose fine sand $>$ sands layer. The fluorine levels for PZ core layers are as follows: gray black clay $>$ faint yellow clay $>$ calcareous nodule $>$ loose fine sand $>$ sands layer. The similar orders of the two cores may be attributed to the same deposition environments.

The sediments in the aquifer show the lowest levels of fluorine. The average fluorine concentrations from top to bottom are 154, 139, 200, $222 \mathrm{mg} / \mathrm{kg}$ for the TS core, and $154,130,266,272 \mathrm{mg} / \mathrm{kg}$ for the PZ core, respectively. Such low levels of fluorine in the granite gravels in the two cores indicate that a vast amount of fluorine was released into the groundwater during the interaction between the rock and water. Although there is still no document that dates the level of fluorine in granite gravels in aquifers, it is acknowledged that the level of fluorine in the granites shows high concentrations. Vinogradov concluded that fluorine content in the granites had an average value of $660 \mathrm{ppm}$ (Wang 1988), and even higher concentrations were reported. Rammohan Rao et al. (1993) reported that fluorine concentrations in granitic rocks from the Nalgonda District ranges from 325 to $3,200 \mathrm{mg} /$ $\mathrm{kg}$ with a mean of $1,440 \mathrm{mg} / \mathrm{kg}$. Fluorine in granites in the southwestern part of Japan reaches $810 \mathrm{ppm}$ (Ye 1984). Li et al. (1985) showed fluorine in granites of Fang City, Henan Province, reached an average of 1,312 ppm. Zhu et al. (2002) compared fluorine concentrations of $\mathrm{Li}-$ $\mathrm{F}$ granitic rocks from different regions all over the world, which showed a range of $600-2,360 \mathrm{ppm}$ with an average of $1,368 \mathrm{ppm}$. Brehler and Fuge (1974) summarized that most granites show a range of $200-2,000 \mathrm{ppm}$. Whereas, Wang (1988) stated that the level of fluorine in the granites in Zhaoyuan-Yexian (also namely Laizhou) area, a region surrounding Laizhou Bay, showed an average level of $590 \mathrm{ppm}$ by a vast amount of samples, even slightly lower than the average. This implies that the level of fluorine in fresh granites around Laizhou Bay does not show high values.

The levels of fluorine in the sediment in the aquifer for the two cores both are characterized by the orders of 2 nd, 1st, 3rd and 4th, indicating a similar sedimentary evolution. The fluorine which leached into the groundwater is associated with the resident time (Brunt et al. 2004; Saxena and Ahmed 2001). However, both cores show lower fluorine concentrations in the upper two layers of sediments than those of the bottom. This may be due to the fact that water in the upper two layers is heavily consumed by the local habitants, and as a result, the groundwater cycles more quickly, and fluorine leaching from granite gravels is intensified. 
Simulation experiment of fluorine release with different solutions and the possible dynamics of fluorine enrichment

Although Wang (1988) stated fluorine concentration in granites around this area is almost equal to the average concentration, the granite gravels in the aquifer show extremely low values. It can be estimated that approximately $70 \%$ fluorine in granite is leached into groundwater with the following equation if the fluorine concentration of $590 \mathrm{mg} / \mathrm{kg}$ (reported by Wang 1988), the average of the neighboring granites, is considered:

$F_{1}(\%)=\frac{F_{\mathrm{r}}-F_{\mathrm{s}}}{F_{\mathrm{r}}} \times 100 \%$

where $F_{1}$ is the percentage of fluorine leachate, $F_{\mathrm{r}}$ is the fluorine contents in fresh granites, and $F_{\mathrm{S}}$ is the fluorine content in granite gravels.

Although the granites do not show higher levels of fluorine around Laizhou Bay, they show high leachability. Rocks determine the amount of fluorine in groundwater from two aspects: Fluorine in the rock itself (Subba Rao and John Devadas 2003) and conditions for leaching (Dowgiatto 2000; Woo et al. 2000; Smedley et al. 2002). Therefore, the release of fluorine is largely governed by the presence of other environmental conditions. One of the most distinctive geologic features in this area is seawater intrusion, which might alter groundwater properties and enhance fluorine leachability.

First, groundwater $\mathrm{Na}^{+}$increases when seawater is intruded, and $\mathrm{Ca}^{2+}$ decreases due to alkaline condition. $\mathrm{Na}^{+}$and $\mathrm{Na}^{+} / \mathrm{Ca}^{2+}$, therefore, increase owing to the seawater intrusion (Wu et al. 1994; Zhang and Peng 1998; Lamia et al. 2009). Such a process potentially promotes fluorine solubility because of the following two reasons: $\mathrm{NaF}$ has higher solubility than $\mathrm{CaF}_{2}$ in water solution, and $\mathrm{Na}^{+}$has more of an affinity to $\mathrm{F}^{-}$than $\mathrm{Ca}^{2+}$ or $\mathrm{Mg}^{2+}$. Several experiments have confirmed that fluorine leachate increased with an increase of $\mathrm{Na}^{+}$and $\mathrm{Na}^{+} / \mathrm{Ca}^{2+}$ (Krainov and Petrova 1976; Krainov and Zakutin 1994; Gao et al. 2007b). The inverse correlation between $\mathrm{F}^{-}$and $\mathrm{Ca}^{2+}$ are often observed in the saturation state (Ozsvath 2009) because the maximum concentration of fluorine is generally restricted by $\mathrm{CaF}_{2}$ (Apambire et al. 1997; Cronin et al. 2000; Saxena and Ahmed 2003).

Second, $\mathrm{HCO}_{3}{ }^{-}$in groundwater was considered as a fluorine enrichment factor due to the following reactions when $\mathrm{Na}^{+}$and $\mathrm{HCO}_{3}{ }^{-}$are adequate (Rammohan Rao et al. 1993; Saxena and Ahmed 2001, 2003; Subba Rao and John Devadas 2003):

$\mathrm{CaF}_{2}+2 \mathrm{HCO}_{3}^{-}=\mathrm{CaCO}_{3}+2 \mathrm{~F}^{-}+\mathrm{H}_{2} \mathrm{O}+\mathrm{CO}_{2}$

$$
\begin{aligned}
\mathrm{CaF}_{2}+2 \mathrm{NaHCO}_{3}= & \mathrm{CaCO}_{3}+2 \mathrm{Na}^{+}+2 \mathrm{~F}^{-}+\mathrm{H}_{2} \mathrm{O} \\
& +\mathrm{CO}_{2}
\end{aligned}
$$

Obviously, more $\mathrm{CaF}_{2}$ in rocks dissolved with an increase in $\mathrm{NaHCO}_{3}$. Thereby, the increased $\mathrm{HCO}_{3}{ }^{-}$in groundwater due to seawater intrusion may be a main dynamic of the high fluorine leachability.

Third, seawater intrusion results in alkaline water. $\mathrm{F}^{-}$ and $\mathrm{OH}^{-}$often replace each other within minerals because of the similar ionic radii. Especially in an environment with a high $\mathrm{pH}, \mathrm{OH}^{-}$often displaces $\mathrm{F}^{-}$, and $\mathrm{F}^{-}$is then released into the groundwater (Sreedevi et al. 2006). Therefore, groundwater with a high level of fluorine usually also has a high $\mathrm{pH}$ value. Alkaline water promotes the release of fluorine and many researches have observed that fluorine leaching is enhanced as the $\mathrm{pH}$ increases (Chae et al. 2007; Chen et al. 2012).

In addition, many studies demonstrated that fluorine enrichment is favored by high salinity, conductivity, TDS and hardness (Ahmed et al. 2002; Chae et al. 2006; Valenzuela-Vasquez et al. 2006; Gao et al. 2007b; Jiang 2008). Such conditions obviously occur due to seawater intrusion and consequently fluorine leaching from rock increases.

A series of studies on fluorine sources and the forming factors in aquifers also concluded that there is a close relationship between high concentrations of fluorine and soft, alkaline groundwater that has low concentrations of $\mathrm{Ca}^{2+}$ and high concentrations of $\mathrm{Na}^{+}$(Robertson 1986; Whittemore et al. 1993; Kierdorf and Kierdorf 2000; Woo et al. 2000; Earle and Krogh 2004; Nordstrom and Ball 2005; Chae et al. 2006, 2007; Walna et al. 2007). In fact, investigation also found that the distribution of fluorosis and the patterns of seawater intrusion in Laizhou Bay have the same trends (Chen et al. 2011, 2012).

More interesting, the simulated results of fluorine leaching from biotite granites are shown in Fig. 7. Figure $7 \mathrm{a}$ indicates fluorine leachability with the addition of seawater. The increased fluorine ions for fresh water solution increase before $24 \mathrm{~h}$, and reach the minimum value of $0.04 \mathrm{mg} / \mathrm{L}$ at $48 \mathrm{~h}$ and the maximum value of $1.12 \mathrm{mg} / \mathrm{L}$ at $96 \mathrm{~h}$, and then begin to decrease at $192 \mathrm{~h}$. The increased fluorine for fresh water and seawater of 1:1, and seawater solutions both have the minimum values of 0.28 and $0.32 \mathrm{mg} / \mathrm{L}$, respectively, at $16 \mathrm{~h}$, and besides that for fresh water and seawater of 1:1 solution shows a decreasing trend after $48 \mathrm{~h}$. Figure $7 \mathrm{~b}$ describes the fluorine concentrations with different mixing of brine water. The fluorine concentrations for the fresh water and brine water of $1: 1$ solution increase before $24 \mathrm{~h}$ and decrease after $96 \mathrm{~h}$, with a maximum of $8.38 \mathrm{mg} / \mathrm{L}$ at $48 \mathrm{~h}$. The brine water shows fluorine trend of decreasing from $8 \mathrm{~h}$ to $16 \mathrm{~h}$ and increasing after $24 \mathrm{~h}$, with the minimum of $4.58 \mathrm{mg} / \mathrm{L}$ at $16 \mathrm{~h}$. Generally, the leaching fluorine for five 

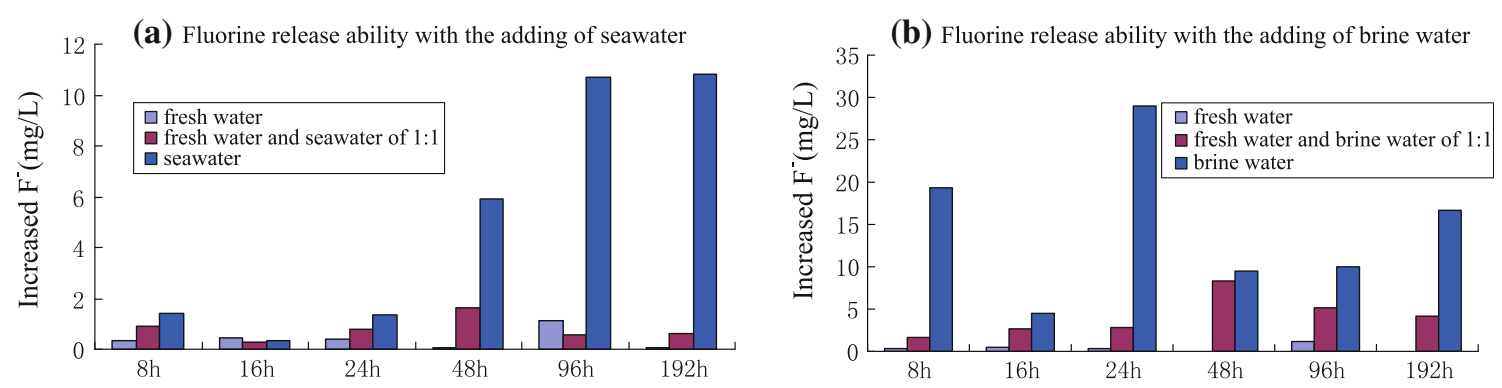

Fig. 7 Simulated results of fluorine release from granites with different solutions

solutions seems to show different variations. One reason may be the complex water-rock interactions process as transformation, self-purification, absorption, dissolution and sedimentation and so on. The other reason is probably attributed to the strong ion exchange interaction during the mixing of seawater and brine water, which influences fluorine levels by changing the equilibrium of $\mathrm{Na}-\mathrm{Ca}-\mathrm{F}$ (Xue et al. 1998; Meng et al. 2002). Also, Wang et al. (2008) found the similar process of $\mathrm{Ca}^{2+}, \mathrm{SO}_{4}{ }^{2-}, \mathrm{Cl}^{-}$ during water-rock interaction.

Despite the complexity of fluorine leaching from rocks, it can be found that the increased fluorine is in the order: seawater $>$ fresh water and brine water of $1: 1>$ fresh water, and brine water $>$ fresh water and brine water of 1:1 > fresh water, except a slightly higher value for fresh water at $16 \mathrm{~h}$ and a slightly lower value for the fresh water and brine water of 1:1 at $96 \mathrm{~h}$. Obviously, the fluorine release ability increases with the adding of seawater or brine water, and such a fact directly confirms that the leaching ability of soil/rock is enhanced with seawater or brine water intrusion in coastal areas.

In fact, not only in the coastal area along Laizhou Bay, but also in other regions, high fluorine concentrations in groundwater occurred in seawater intrusion areas. For example, a high incidence of fluorosis along the coastal region of Liaoning Province, China was found (Kou and Wang 2000). Further, salt lake water intrusions, a process similar to seawater intrusion, take place in Yuncheng, Shanxi Province of China and Nagar Parker, Sindh Province of Pakistan, and experiments have confirmed to increase rock fluorine leachability and elevate fluorine concentrations due to the under saturation with respect to fluorite in these areas (Gao et al. 2007b; Tahir et al. 2009).

\section{Conclusions}

Two sediment cores were drilled in Changyi County and Laizhou County along Laizhou Bay, where the widespread fluorosis of drinking water occurs. The fluorine concentrations in the two cores were studied to determine the sources of fluorine in the groundwater and the enrichment dynamics, and the following was ascertained:

1. It was found that the sediment in the aquifer was composed of weathered, granite gravels. Thus, the granites of the Yanshanian Phase, widely distributed in the northeastern part of the coastal region of Laizhou Bay, seem to be responsible for the enrichment of groundwater with fluorine. Such a result is in agreement with the previous findings.

2. The fluorine concentrations of the PZ and TS cores range at $130-468,139-528 \mathrm{mg} / \mathrm{kg}$, with average values of $324,348 \mathrm{mg} / \mathrm{kg}$, respectively. They do not show high levels, the levels of fluorine in sediment cannot explain the fluorine enrichment in groundwater. However, the average fluorine concentrations in the aquifer from top to bottom are 154, 139, 200, $222 \mathrm{mg} /$ $\mathrm{kg}$ for the TS core, and 154, 130, 266, $272 \mathrm{mg} / \mathrm{kg}$ for the PZ core, respectively. This shows extremely low levels of fluorine and indicates that a vast amount of fluorine was leached into the groundwater.

3. The document showed fluorine concentrations in the granite surrounding Laizhou Bay are almost equal to or even lower than the average values; however, the leachability of fluorine is approximately $70 \%$. One of the most distinctive geologic features in this area, the existence of seawater intrusion, may potentially enhance the ability of fluorine to leach into the groundwater. Meanwhile, the simulation experiment also indicates that fluorine leaching from rocks increases with the adding of seawater or brine water.

Acknowledgments This work is supported by Natural Science Fund of China (No. 40901027, 41106036), the Natural Science Fund of Shandong Province (ZR2011DQ006), the International Partnership Creative Group, the Chinese Academy of Sciences "Typical Environmental Process and Effects of Coastal Zone Resources", the National Training Programs of Innovation and Entrepreneurship for Undergraduates, and we are grateful for two anonymous reviewers' advices. 


\section{References}

Ahmed S, Sreedevi PD, Sujatha D, Hashimi SAR, Subrahmanyam K, Saxena VK (2002) Time-variant behavior of fluoride contents in granitic aquifers. Presented during the international groundwater conference, 20-22 February 2002, in Dindigul, Tamilnadu, India

Apambire WB, Boyle DR, Michel FA (1997) Geochemistry, genesis and health implications of fluoriferous groundwater in the upper regions of Ghana. Environ Geol 33:13-24

Brehler B, Fuge R (1974) Chlorine. In: Wedepohl KH (ed) Handbook of geochemistry. Springer, Berlin, 17-A-17-O

Brunt R, Vasak L, Giffioen J (2004) Fluoride in groundwater: probability of occurrence of excessive concentration on global scale. International Groundwater Resources Assessment Centre (IGRAC). Report SP 2004-2, Utrecht

Carrillo-Rivera JJ, Cardona A, Edmunds WM (2002) Use of abstraction regime and knowledge of hydrogeological conditions to control high-fluoride concentration in abstracted groundwater: San Luis Potosi basin, Mexico. J Hydrol 261:24-47

Chae GT, Yun ST, Kim K, Mayer B (2006) Hydrogeochemistry of sodium-bicarbonate type bedrock groundwater in the Pochon Spa Area, South Korea: water-rock interaction and hydrologic mixing. J Hydrol 321:326-334

Chae GT, Yun ST, Mayer B, Kim KH, Kim SY, Kwon JS (2007) Fluorine geochemistry bedrock groundwater of South Korea. Sci Total Environ 385:272-283

Chen Q, Liu DY, Lu QS, Di BP, Shi WJ (2011) Impacts of seawater intrusion on the fluorine content in groundwater: A case study in Shandong Province. Paper presented at the 5th international conference on bioinformatics and biomedical engineering (iCBBE (2011)) in China, 3880-3884

Chen Q, Song ZJ, Lu QS, Wang M, Feng JG, Hong T, Liu JY, Li XH, Zhang R (2012) Fluorine contents and its characteristics of groundwater in fluorosis area in Laizhou Bay. China, Toxicol Environ Chem 94(8):1490-1501

Cronin SJ, Manoharan V, Hedley MJ, Loganathan P (2000) Fluoride: a review of its fate, bioavailability, and risks of fluorosis in grazedpasture systems in New Zealand. New Zeal J Agr Res 43:295-321

Dowgiatto J (2000) Thermal water prospecting results at Jelenia Gora-Cieplice (Sudetes, Poland) versus geothermometric forecasts. Environ Geol 39:433-437

Earle S, Krogh E (2004) Geochemistry of Gabriola's groundwater. Shale J Gabriola His Mus Soc 7:35-42

Fantong WY, Satake H, Aka FT, Ayonghe SN, Asai K, Mandal A, Ako AA (2010) Hydrochemical and isotopic evidence of recharge, apparent age, and flow direction of groundwater in Mayo Tsanaga River Basin, Cameroon: bearings on contamination. Environ Earth Sci 60:107-120

Farooqi A, Masuda H, Firdous N (2007) Toxic fluoride and arsenic contaminated groundwater in the Lahore and Kasur districts, Punjab, Pakistan and possible contaminant sources. J Environ Pollut 145:839-849

Faure G (1991) Principles and applications of inorganic geochemistry. Macmillan Publishing Company, New York

Fuge R (1988) Sources of halogens in the environment, influences on human and animal health. Environ Geochem Health 10:51-61

Gaciri SJ, Davies TC (1993) The occurrence and geochemistry of fluoride in some natural waters of Kenya. J Hydrol 143:395-412

Gao HX, Wang YT, Zhu WS, Lu XD, Chen PZ, Yun ZJ, Ma AH, Zhao LJ (2007a) Investigation on the status of endemic fluorosis in Binzhou in 2005. Prev Med Trib 13:807-815

Gao XB, Wang YX, Li YL, Guo QH (2007b) Enrichment of fluoride in groundwater under the impact of saline water intrusion at the salt lake area of Yuncheng Basin, Northern China. Environ Geol 53:795-803
Han M (1997) The effects of seawater intrusion to economy and society in Laizhou Bay region. J Nat Disasters 6:82-88

Harrison Paul TC (2005) Fluoride in water: a UK perspective. J Fluor Chem 126:1448-1456

Jiang H (2008) High-fluorine groundwater in eastern Henan Yellow River alluvial plain and drinking water safety. Explor Sci Technol 2:49-53

Kanisiwa S (1979) Content and behavior of fluorine in granitic rocks, Kitakami Mountains, Northeast Japan. Chem Geol 24:57-67

Kierdorf U, Kierdorf H (2000) The fluoride content of antlers as an indicator of fluoride exposure in red deer (Cervus elaphus): a historical biomonitoring study. Environ Contam Toxicol 38(1):121-127

Kim K, Jeong GY (2005) Factors influencing natural occurrence of fluoride-rich groundwaters: a case study in the southeastern part of the Korean Peninsula. Chemosphere 58(10):1399-1408

Kou YJ, Wang Y (2000) Genesis and controlling measures of marine invasion in Liaoning Province. Liaoning Geol 17(1):67-71

Krainov SR, Petrova NG (1976) Fluorine-bearing groundwater, their geochemical characteristics, and the effect on biological processes. Geokhimiya 10:1533-1541

Krainov SR, Zakutin VP (1994) Geochemical and environmental state of groundwater in Russia (the causes and tendencies in the changes of groundwater chemistry). Geokhimiya 3:312-329

Lahermo P, Sandstrom H, Malisa E (1991) The occurrence and geochemistry of fluorides in natural waters in Finland and East Africa with reference to their geomedical implications. J Geochem Explor 41:65-79

Lamia K, Abdalah BM, Mennoubi SF (2009) Seawater intrusion and associated processes: case of the korba aquifer (Cap-Bon, Tunisia). CR Geosci 341(1):21-35

Li CX (2007) Genesis analysis of high-fluorine underground water in Gaomi area of Shandong Province. Shandong Land Resour 23(8):8-11

Li RB, Tan JA, Wang LZ, Zheng DX, Wang WY (1985) The fluoride content in the cultivated soil under different geographical condition in China and its relation to endemic fluorosis. Geogr Res 4(1):30-40

Li Z, Tainosho Y, Shiraishi K (2003) Chemical characteristics of fluorine bearing biotite of early Paleozoic plutonic rocks from the Sor Rondane Mountains, East Antarctica. Geochem J 37:145-161

Luo ZK, Miao LC (2002) Granites and Au deposits in ZhaoyuanLaizhou area in eastern Shandong. Metallurgical Industry Press, Beijing

McQuaker NR, Gurney M (1977) Determination of total fluoride in soil and vegetation using an alkali fusion selective ion electrode technique. Anal Chem 49(1):53-56

Meng GL, Han YS, Wang SQ, Wang ZY (2002) Seawater intrusion types and regional divisions in the southern coast of Laizhou Bay. Chin J Oceanol Limnol 20:277-284

Nagadu B, Koeberl C, Kurat G (2003) Petrography and geochemistry of the Singo granite, Uganda, and implications for its origin. J Afr Earth Sci 36:73-87

Nordstrom DK, Ball JW, McCleskey RB (2005) Ground water to surface water: chemistry of thermal outflows in Yellowstone National Park. In: Inskeep WP, McDermott TR (eds) Geotherm Biol Geochem YNP, Chapter 4, pp 73-94

Ozsvath DL (2009) Fluoride and environmental health: a review. Rev Environ Sci Biotechnol 8(1):9136-9144

Ramanaiah SV, Venkatamohan S, Rajkumar B, Sarma PN (2006) Monitoring of fluoride concentration in groundwater of Prakasham district in India: correlation with physico-chemical parameters. J Environ Sci Eng 48:129-134

Rammohan Rao NV, Rao N, Rao KSP, Schuiling RD (1993) Fluorine distribution in waters of Nalgonda District, Andhra Pradesh. India Environ Geol 21(1-2):84-89 
Reddy DV, Nagabhushanam P, Sukhija BS, Reddy AGS, Smedley PL (2010) Fluoride dynamics in the granitic aquifer of the Wailapally watershed, Nalgonda District, India. Chem Geol 269:278-289

Robertson FN (1986) Occurrence and solubility controls of trace elements in groundwater in alluvial basins of Arizona. In: Anderson TW, Johnson AI (eds) Regional aquifer systems of the United States, Southwest alluvial basins of Arizona, American Water Resources Association Series \#7. American Water Resources Association, Arizona, pp 69-80

Saxena VK, Ahmed S (2001) Dissolution of fluoride in groundwater: a water-reaction study. Environ Geol 40:1084-1090

Saxena VK, Ahmed S (2003) Inferring the chemical parameters for the dissolution of fluoride in groundwater. Environ Geol 43:731-736

Scaillet B, Macdonald R (2004) Fluorite stability in silicic magmas. Contrib Mineral Petr 147(3):319-329

Smedley PL, Nicolli HB, Macdonald DMJ, Barros AJ, Tullio JO (2002) Hydrogeochemistry of arsenic and other inorganic constituents in groundwaters from LaPampa, Argentina. Appl Geochem 17:259-284

Sreedevi PD, Ahmed S, Made B (2006) Association of hydrological factors in temporal variations of fluoride concentration in a crystalline aquifer in India. Environ Geol 50:1-11

Subba Rao N, John Devadas D (2003) Fluoride incidence in groundwater in an area of Peninsular India. Environ Geol 45:243

Tahir R, Shahid N, Tanzil HU (2009) Geochemical factors controlling the occurrence of high fluoride groundwater in the Nagar Parkar area, Sindh, Pakistan. J Hazard Mater 171:424-430

Taylor RP, Fallick AE (1997) The evolution of fluorine-rich felsic magmas: source dichotomy, magmatic convergence and the origins of Topaz Granite. Terra Nova 9(3):105-108

Valenzuela-vasquez L, Ramirez-Hernandez J, Reyes-lopez J, SolUribe A, Lazaro-Mancilla O (2006) The origin of fluoride in groundwater supply to Hermosillo City, Sonora, Mexico. Environ Geol 51:17-27

Walna B, Kurzyca I, Siepak J (2007) Variations in fluoride level in precipitation in a region of human impact. Water Air Soil Pollut Focus 7(1-3):33-40

Wang BC (1988) Study on the geologic and geochemical characteristics and genesis of the porphyritic granites in the ZhaoyuanYexian area in Shandong province. Shandong Geol 4(1):45-66
Wang Y, Wei FS (1995) Chemistry of elements in the pedosphere environment. China Environmental Science Press, Beijing

Wang LG, Li XL, Liu L, Han L (2008) Research on mechanism of groundwater pollution from mine water in abandoned mines. J Coal Sci Eng (China) 14(2):294-298

Whittemore DO, Macfarlane PA, Doveton JH (1993) The Dakota aquifer program annual report, FY92. Kansas Geological Survey open-file report 93-1

WHO (1984) Guidelines for drinking water quality (vol. II: health criteria and supporting information. Geneva, Switzerland: World Health Organization

Woo NC, Moon JW, Won JS, Hahn JS, Lin XY, Zhao YS (2000) Water quality and pollution in Hunchan Basin, China. Environ Geochem Health 22:1-18

Wu JC, Xue YQ, Liu PM, Wang JJ, Jiang QB, Shi HW, Ning PH (1994) Development and hydrochemical characteristic of seawater intrusion in Longkou-Laizhou district. J Nanjing Univ (Nat Sci Ed) 30:98-110

Xie ZM, Wu WH, Xu JM (1999) Translocation and transformation of fluorides in the environment and their biological effects. Adv Environ Sci 7(2):40-53

Xiong XL, Zhu ZH (1998) Partitioning of F between aqueous fluids and albite melt and its petrogenetic and metallogenetic significance. Chin J Geochem 17(4):303-310

Xue YQ, Wu JC, Xie CH, Zhang YX (1998) Sea water intrusion and salt water intrusion in the coastal area of Laizhou Bay. Chinese Sci Bull 43(12):983-992

Ye SG (1984) Fluorine, chlorine action in granitic magma. Acad J Guilin Metall Geol 4:187

Yun ZJ, Chen PZ, Biao JC, Hao JT, Gao XH, Qin YP, Wang YT, Ma AH (2005) Analysis of water fluoride content in endemic fluorosis region in Shandong Province. Chin $\mathrm{J}$ Endemiol 24:551-553

Zhang ZL, Peng LM (1998) The underground water hydrochemical characteristics on sea water intruded in eastern and southern coasts of Laizhou Bay. China Environ Sci 18:121-124

Zhu JC, Rao B, Xiong XL, Li FC, Zhang PH (2002) Comparison and genetic interpretation of $\mathrm{Li}-\mathrm{F}$ rich, rare-metal bearing granitic rocks. Geochimica 31(2):141-152 